\title{
Canonisation, Colonisation, and the Rise of Neo-Victorianism
}

\section{Abstract:}

Over the last two decades, contemporary culture has witnessed the rapidly increasing popularity of neo-Victorian (literary, filmic, and stage) texts and the development of critical interest in the field. The neo-Victorian genre was initially construed as a subgenre of postmodernism, but more recently has been considered in relation to broader literary and cultural trends. This essay considers the construction of the neo-Victorian canon, and contends that its formation follows the same trajectory as that of the broader literary canon in the early twentieth century, initially excluding or marginalising particular works (in particular, popular fiction and culture) prior to expanding to include a wider array of texts and genres, including, in recent years, global literatures. I map the development of the neoVictorian canon to date, including critical debates around the genre, and examine the implications of this in terms of prevailing attitudes towards literary and cultural scholarship, popular culture, and textual colonisation, before considering the (sometimes problematic) usage and connotations of the terminology associated with this key genre of contemporary fiction. I consider the potential problems of the genre's rapid cultural and critical expansion, and in the conclusion to the essay, suggest some possible future directions for neo-Victorian scholarship in terms of the continued canonical expansion and its ethical framework.

\section{Introduction}

In recent years, one of the most notable trends in the study of contemporary literature and culture has been the emergence and development of neo-Victorianism. Critical interest in contemporary - particularly postmodern - works which engage with the nineteenth-century dates to the 1960s, a decade which witnessed the publication of two seminal texts in this 
field: Jean Rhys's Wide Sargasso Sea (1966) and John Fowles's The French Lieutenant's Woman (1969). The field has developed rapidly since the 1990s, with the genre's reputation cemented by a slew of literary awards for works by authors including A. S. Byatt, Graham Swift, and Sarah Waters. These writers have attracted significant scholarly attention, particularly from those critics interested in postmodernism and historiographic metafiction. ${ }^{1}$ In 2008, the launch of the journal Neo-Victorian Studies cemented 'neo-Victorian' as the preferred nomenclature for contemporary texts engaging with Victorian literature and culture. $^{2}$ Its emergence marked a pivotal moment in the developing field of neo-Victorian scholarship, not least as a consequence of the journal's attempts - drawing on earlier criticism - to identify and define a neo-Victorian canon. This essay considers the emergence and development of the neo-Victorian canon to date, and contends that its formation follows the same trajectory as that of the broader literary canon in the early twentieth century, initially excluding or marginalising certain works and forms (in particular, popular culture) prior to expanding to include a wider array of works, including in recent years, global literatures. I examine the implications of these developments in terms of prevailing attitudes towards scholarship, popular culture, and literary/cultural colonisation, before considering the (sometimes problematic) usage and connotations of the terminology associated with this key area of contemporary culture in relation to the genre's ongoing canonical (global) expansion, and the possible future direction of neo-Victorianism.

\section{Patterns of Canonisation}

\footnotetext{
${ }^{1}$ The term was originally coined by Linda Hutcheon in A Poetics of Postmodernism: History, Theory, Fiction (Abingdon: Routledge, 2003).

2 Critical definitions of the term 'neo-Victorian', along with other possible terms for the genre, are explored further in Andrea Kirchknopf's '(Re)Workings of Nineteenth-Century Fiction: Definitions, Terminology, Contexts' Neo-Victorian Studies, 1.1 (Autumn 2008), 53-80.
} 
The formation of the neo-Victorian canon parallels the establishment of the wider literary canon in the early twentieth century. Certain 'literary' works are initially privileged, prior to canonical expansion to include a broader range of genres and media, including popular fiction, film, television and stage productions, and heritage and other cultural and political events and movements. This mimics the introduction of a broader range of genres and forms into the academic canon post-1960s in the wake of the development of cultural and feminist studies. Neo-Victorian canon formation and development thus serves as a microcosm for the formation of the literary canon in the early twentieth century: beginning by recognising select (highbrow) texts as central, whilst marginalising other works (particularly popular texts), raising significant questions about contemporary critical attitudes towards literature, and the perceived hierarchical 'value' of various types of fiction. This process of canonisation is initially expressed through justifications for the inclusion and exclusion of certain texts, and attempts to defend the canon, before expanding to evolve a more inclusive standard Harold Bloom's The Western Canon (1994) marks a late example of this within broader literary studies, while Ann Heilmann and Mark Llewellyn engage in a similar process within neo-Victorian studies when they distinguish between neo-Victorian work and 'historical fiction set in the nineteenth century'. ${ }^{3}$ A. S. Byatt, commenting on Bloom's work, states:

Bloom's canon is in many ways mine. It consists of those writers all other writers have to know and by whom they measure themselves. A culture's canon is an evolving consensus of individual canons. Canonical writers changed the medium,

\footnotetext{
${ }^{3}$ Ann Heilmann and Mark Llewellyn, Neo-Victorianism: The Victorians in the Twenty-First Century, 1999-2009 (Basingstoke: Palgrave Macmillan, 2010), p.6.
} 
the language they were working in. People who merely describe what is happening now don't last. ${ }^{4}$

In the context of neo-Victorianism, the comment is significant, reinforcing notions of a literary hierarchy, and implicitly alluding to the perceived difference between neo-Victorian and historical fiction: historical fiction set in the nineteenth century, if we situate Byatt's comment alongside Heilmann and Llewellyn's distinction, can be seen as merely descriptive, whereas 'neo-Victorian' writing (according to certain critical definitions) offers a more significant intellectual engagement with the period.

Over the course of time, literary canons expand and the value of previously marginalised works is recognised. As Richard Ohmann observes, 'at any given moment categories embody complex social relations and a continuing historical process'. ${ }^{5}$ Even after this process of expansion has taken place, the 'highbrow' retains its dominant position: traditionally canonical texts remain prominent on Victorian literature modules at universities, with later additions of popular texts (for example, sensation fiction) serving primarily as adjuncts. The literature of the nineteenth century studied by school students remains almost entirely indebted to the original canon. What, then, is the significance of this? Does this method of canon formation essentially enable the continued privileging of highbrow texts? Does the popular remain marginalised in spite of its eventual inclusion - as an afterthought? Why this initial opposition to the popular, subsequently followed by an acknowledgement of its significance? And to what extent is this pattern replicated within the neo-Victorian genre? The resistance towards the inclusion of popular fiction in the wider

\footnotetext{
${ }^{4}$ Quoted in Tim Lawrence and Peter Guttridge, 'Reloading the Ancient Canon', The Independent (21 November 1994), p. 23.

${ }^{5}$ Richard Ohmann, 'The Shaping of a Canon: U.S. Fiction 1960-1975', Critical Inquiry, 10 (1983), pp. 199-223, p. 199.
} 
canon can be traced in part to the association between the literary canon and Kantian aesthetics. Bloom proposes that 'aesthetic value' is not merely a 'suggestion of Immanuel Kant's' but 'an actuality'. ${ }^{6}$ Popular fiction sits uncomfortably with such definitions of canonicity as it does not prioritise aesthetic value, thus calling into question its status in relation to the canon: if we accept such definitions, must popular texts inevitably remain outside the canon, as non-canonical works, even as they are increasingly included in scholarship and university syllabi (two areas traditionally used to define the canon)?

The focus on the 'highbrow' in the formative years of neo-Victorian studies suggests a regressive attitude towards literary criticism: certain authors and genres are privileged over and above others - in both cases these authors are almost exclusively white, western, and 'highbrow' (in the case of the earlier canon they are also predominantly male). Until recently, there has been a critical resistance towards the 'popular' within neo-Victorianism, effectively mimicking the attitude of early twentieth-century scholars, such as F. R. and Q. D. Leavis, who viewed popular bestsellers as not only unworthy of critical investigation, but as potentially damaging to the reader. ${ }^{7}$ While Victorian studies, and literary studies more broadly, has come to acknowledge the significance of popular forms of fiction, there was some initial resistance to this within neo-Victorian scholarship. Criticism situating itself within the neo-Victorian debate tended to privilege 'literary' fiction over and above other genres and mediums: discussions of popular fiction and screen adaptations engaging with Victorian literature and culture, until relatively recently, have tended to take place within

\footnotetext{
${ }^{6}$ Harold Bloom, The Western Canon: The Books and School of the Ages (New York: Macmillan, 1995), p. 1.

${ }^{7}$ In Fiction and the Reading Public (London: Chatto and Windus, 1932), Q. D. Leavis, discussing the public appetite for 'bestsellers', claims 'the reading habit is now often a form of the drug habit' (p. 7), and contends 'One of the great evils of present-day reading is that it discourages thought' (p. 56). This in turn echoes nineteenth-century critics' attitudes to the Victorian sensation novel - a genre accused of 'preaching to the nerves instead of the judgment' (H. L. Mansel, 'Sensation Novels', Quarterly Review, 113.226 [1863], 481-514 (p. 482).
} 
the discourses of popular culture and adaptation studies, ${ }^{8}$ although evidence suggests that this is now shifting. There are various theories we might posit to explain these initial exclusions. The privileging of literature over other types of media reflects the origins of neoVictorianism as a field of primarily literary scholarship. The prioritising of 'literary' fiction reflects the tendency of literature studies more generally to focus predominantly on 'literary' texts, its concern with the aesthetics of fiction - in contradistinction to cultural studies, for example. This literary exclusivity also reflects neo-Victorian scholarship's initial desire to establish its own critical credentials, and to distance itself from popular culture discourses, which seek to emphasise the significance of the low and middlebrow: essentially a claim to its own 'highbrow' status. It is evident that the boundaries of the field are now shifting, and indeed the relatively slow pace of change can be ascribed, in part at least, to the slowness of academic publishing processes, as much as to an early reluctance amongst neo-Victorian scholars to expand beyond the bounds of 'literary' fiction.

Nadine Boehm-Schnitker and Susanne Gruss suggest that 'within neo-Victorianism as an academic discipline, the plea for a clear-cut definition of the field is symptomatic of practices of canonisation', ${ }^{9}$ implying an association between neo-Victorian canon formation and the discipline's need to define itself in a clearly identifiable way: expanding the canon to include all texts which engage in any number of ways with the Victorian era risks losing that sense of identity that comes from a clearly articulated definition - as is evident from more recent critical definitions. Again, we might see this as an attempt to secure intellectual

\footnotetext{
${ }^{8}$ Robert Gidding's and Erica Sheen's edited collection The Classic Novel from Page to Screen (Manchester: Manchester University Press, 2000) and Diane Sadoff's Victorian Vogue: British Novels on Screen (Minneapolis: University of Minnesota Press, 2009) do not engage directly with the discourses of neo-Victorianism. By contrast, Iris Kleinecke-Bates's recent work Victorians on Screen: The Nineteenth Century on British Television, 1994-2005 (Basingstoke: Palgrave Macmillan, 2014) clearly situates itself within neo-Victorian scholarship, indicating the recent trend towards a more inclusive definition of the genre.

${ }^{9}$ Nadine Boehm-Schnitker and Susanne Gruss, eds, 'Introduction', Neo-Victorian Literature and Culture: Immersions and Revisitations, (Abingdon: Routledge, 2014), pp. 1-17 (p. 3).
} 
legitimacy, or to stake a particular claim for specific texts. Nonetheless, as the critical field of neo-Victorian studies continues to follow the trajectory of wider literary canon formation, it is expanding to engage with far broader array of texts. As Margaret Stetz observes, already 'neo-Victorian texts are everywhere, inside and outside of the academy, and most certainly throughout both transatlantic and postcolonial literary and popular culture' ${ }^{10}$ This raises important questions about the nature of the neo-Victorian canon: if we include all texts which engage with the Victorian, does this necessitate the deconstruction, rather than merely the expansion, of the canon, since its inclusiveness reduces the representative nature of canonical texts? What are the implications of this ubiquity, particularly in relation to how we conceive of the meanings behind the term 'neo-Victorian'? The remainder of this essay seeks to address these questions, mapping the neo-Victorian canon to date, exploring its (literary/cultural) hierarchies and shifting criteria, and examining the manner in which this emerging ubiquity serves to disrupt the meanings of the term through an exploration of the genre's tendency to reach beyond its own self-defined borders, and colonise other literatures.

\section{Mapping the Neo-Victorian Canon}

In her review of Ann Heilmann and Mark Llewellyn's Neo-Victorianism: The Victorians in the Twenty-First Century, $1999-2009$ (2010), ${ }^{11}$ Marie-Luise Kohlke notes that, while primarily focused on works published since 1999, 'passing references to such works as John Fowles' The French Lieutenant's Woman (1969) or A. S. Byatt's Possession: A Romance

\footnotetext{
10 Margaret Stetz, 'Neo-Victorian Studies', Victorian Literature and Culture, 40.1 (March 2012), $339-46$ (p. 345).

11 Heilmann and Llewellyn's expansion of the 'twenty-first century' to include the final two years of the twentieth century mirrors neo-Victorianism's tendency to extend its range beyond those years specifically connected with Victoria's reign - a point I return to later.
} 
(1990) are included to contextualise more recent aesthetic developments'. ${ }^{12}$ The contextualisation provided by Fowles and Byatt is perceived as necessary because they stand as genre-defining authors within neo-Victorianism - their works widely acknowledged as effectively originating the canon, as it has come to be defined by literary scholarship. These texts, along with a select number of others, including titles by Peter Ackroyd, Michel Faber, Graham Swift, and Sarah Waters, are repeatedly revisited by neo-Victorian scholarship, in a process of insistent returning which mirrors the intrinsic patterns of the genre itself in terms of its recurrent engagements with Victorian literature and culture something which Kohlke terms a 'repetition compulsion'. ${ }^{13}$ Early works of neo-Victorian criticism continually cite these texts as exemplars of the field, reaffirming their position as contextual documents for situating the genre itself in later scholarship on the neo-Victorian phenomenon. Their authors share a number of common traits: they are predominantly white, British, and, significantly, producers of 'highbrow', literary fiction, appearing regularly on the Booker and other prestigious literary prize shortlists. Byatt's Possession won the award in 1990, while another of her neo-Victorian works, The Children's Book (2009) was also shortlisted, as well as winning the James Tait Black Memorial Prize. Swift, like Byatt, is a recipient of both these prizes (although not for his neo-Victorian fiction), while Ackroyd and Waters have also been nominated for the Booker Prize, and have won a slew of other awards. ${ }^{14}$ Such writers, then, belong very clearly to the 'literary establishment'. ${ }^{15}$ Other key

\footnotetext{
12 Marie-Luise Kohlke, 'A Neo-Victorian Smorgasbord: Review of Ann Heilmman and Mark Llewellyn's NeoVictorianism: The Victorians in the Twenty-First Century, 1999-2009', Neo-Victorian Studies, 3.2 (2010), 206-17 (p. 206). Kohlke's reference to aesthetics is also significant here, echoing notions of the Kantean aesthetic at the heart of critical constructions of the literary canon.

${ }^{13}$ Marie-Luise Kohlke, 'Mining the Neo-Victorian Vein: Prospecting for Gold, Buried Treasure, and Uncertain Metal' in Neo-Victorian Literature and Culture, pp. 21-37 (p. 21).

${ }^{14}$ Ackroyd won the 1984 Somerset Maugham Award for The Last Testament of Oscar Wilde and was shortlisted for the Booker Prize for Chatterton in 1988. Waters's nominations and awards include the Betty Trask award for Tipping the Velvet (1999), the Stonewall Book and Somerset Maugham awards for Affinity
} 
texts within neo-Victorianism boast similar credentials: Rhys's Wide Sargasso Sea $^{16}$ and Peter Carey's Oscar and Lucinda (1988) and Jack Maggs (1997), for example. ${ }^{17}$ Rhys's and Carey's novels differ from those of Byatt and Waters by virtue of their status as postcolonial texts, but nonetheless it is on the basis of their highbrow style rather than their (post)colonial content that they seem to have been of interest to neo-Victorian critics. ${ }^{18}$ Indeed, the association between these narratives and the traditional literary canon is signified by their engagement with texts and authors long-recognised as canonical within English literature: Charlotte Brontë, Thomas Hardy, Robert Browning, Christina Rossetti, and Charles Dickens. To this end, these works self-consciously declare their affiliation with the traditional literary canon.

The privileged position of these works within neo-Victorian scholarship to date is evident from a brief review of criticism and university syllabi, the latter frequently perceived as an important indicator of canonical status. ${ }^{19}$ Byatt, Fowles, and Waters in particular remain ubiquitous on undergraduate and postgraduate modules on neo-Victorianism, ${ }^{20}$ although in recent years, such modules, like the neo-Victorian canon itself, have expanded to include a more diverse range of works, including popular fiction, film, television, and

(2000), Booker and Orange Prize nominations for Fingersmith (2002), and shortlisting for the Booker Prize for The Little Stranger (2009).

${ }^{15}$ This is a problematic and contested term. Geoff Dyer refers to it as a 'mythic beast' ('The Literary Establishment and Me', The Guardian, 16 March 2012, https://www.theguardian.com/books/2012/mar/16/author-geoff-dyer-literary-establishment). I use it here very generally - to allude to those writers who have achieved critical success and recognition.

${ }^{16}$ Rhys's novel won the W H Smith Literary Award in 1967. In Nostalgic Postmodernism, Christian Gutleben cites Rhys's novel as inaugurating what would subsequently become known as the neo-Victorian genre (Nostalgic Postmodernism: The Victorian Tradition and the Contemporary British Novel [Amsterdam: Rodopi, 2001], p. 5).

17 Oscar and Lucinda won the Booker Prize in 1988; Jack Maggs was awarded the Commonwealth Writers Prize, and a range of other awards, in 1997.

${ }^{18}$ Significantly, both Rhys and Carey are white and write more or less within the milieu of the literary metropole - factors which may be relevant to their inclusion within the neo-Victorian canon.

${ }^{19}$ For a discussion of the sometimes problematic relationship between the canon and the syllabus, see John Guillory's Cultural Capital: The Problem of Literary Canon Formation (University of Chicago Press, 1993), particularly chapter one: 'Canonical and Noncanonical: The Current Debate'.

${ }^{20}$ Neo-Victorian modules taught at UK universities including Cardiff, Northumbria, Leeds Met, Manchester, and Loughborough, and US universities including Brown and Winthrop. All include at least two of these authors. 
graphic novels. ${ }^{21}$ Similarly, early criticism in the field of neo-Victorianism places a strong emphasis on the work of 'highbrow' literary authors. ${ }^{22}$ Articles from the 1990s, when neoVictorianism first began to emerge as a school of literary criticism distinct from postmodernism and historiographic metafiction, indicate the extent to which the field privileged the 'highbrow' over the popular. Kelly Marsh's 1995 article 'The Neo-Sensation Novel: A Contemporary Genre in the Victorian Tradition', ${ }^{23}$ despite its concern with contemporary writing's relationship to Victorian popular fiction, uses the examples of Swift's Waterland (1983) and Byatt's Possession, electing to focus on 'highbrow' rather than popular descendants of Victorian sensation fiction. Dana Shiller, in her 1997 essay 'The Redemptive Past in the Neo-Victorian Novel', ${ }^{24}$ also considers Possession, alongside Ackroyd's Chatterton (1987). In 'Natural History: The Retro-Victorian Novel', Sally Shuttleworth examines Byatt's Angels and Insects (1992) and Swift's Ever After (1992). ${ }^{25}$ The trend continued in the early years of the twenty-first century, with 'canonical' neoVictorian writers featuring heavily - and, I suggest, disproportionately - in scholarly works, including Suzanne Keen's Romances of the Archive in Contemporary British Fiction (2001), Christian Gutleben's Nostalgic Postmodernism (2001), and Daniel Candel Bormann's The Articulation of Science in the Neo-Victorian Novel (2002). ${ }^{26}$ By contrast, commercially successful historical fiction set in the Victorian period, such as Elizabeth Peters's historical

\footnotetext{
${ }^{21}$ Both Liverpool and Northumbria Universities include graphic novels on their neo-Victorian modules. The latter also features film and performance. Crime fiction features on Swansea's neo-Victorian module.

${ }^{22}$ Some of this criticism inevitably pre-dates the emergence of 'neo-Victorian' as the favoured critical term for the genre.

${ }^{23}$ Kelly Marsh, 'The Neo-Sensation Novel: A Contemporary Genre in the Victorian Tradition', Philological Quarterly 74.1 (Winter 1995), 99-123.

${ }^{24}$ Dana Shiller, 'The Redemptive Past in the Neo-Victorian Novel', Studies in the Novel 29.4 (Winter 1997), 53860. Shiller's article includes one of the earliest critical uses of the term 'neo-Victorian'.

${ }^{25}$ Sally Shuttleworth, 'Natural History: The Retro-Victorian Novel', in The Third Culture: Literature and Science, ed. by Elinor S. Shaffer (Berlin: Walter de Gruyter, 1998), pp. 253-68.

${ }^{26}$ Amongst the neo-Victorian writers discussed by Keen are Byatt and Julian Barnes; Gutleben's subjects include Byatt, Fowles, and Swift; Bormann uses two 'case studies' in his work: Byatt's Possession and Swfit's Waterland.
} 
detective series featuring Amelia Peabody, has thus far attracted limited critical attention within neo-Victorian studies.

These trends are similarly apparent in the journal, Neo-Victorian Studies. Here, too, 'literary' authors are well represented, with the first issue including articles on both Waters and Byatt, although an article on Steampunk also appeared. More recently, the journal has included an increasing amount of criticism on popular culture alongside discussions of these 'canonical' writers, and thereby contributed to a broadening of the canon. ${ }^{27}$ Thus, in the rapid development of neo-Victorian criticism over the past decade, while scholarship has continued to privilege 'literary' authors over popular fiction and culture, ${ }^{28}$ the popular is shifting in from the margins. This is an implicit acknowledgement of both the widespread influence of Victorian popular writing on neo-Victorian texts, and of contemporary popular fiction's persistent engagement with Victorian literature and culture, as well as a recognition of the relevance of critical discourses on popular culture to the field. ${ }^{29}$ Increasingly, then, neo-Victorianism is expanding its critical boundaries to incorporate a variety of disciplinary and scholarly approaches, which move it beyond the discourses of postmodernism and historiographic metafiction.

\section{(Literary) Hierarchies: Defining the Neo-Victorian}

The question remains of why works of 'literary' fiction have historically been privileged over and above other texts. The answer lies partly, I suggest, within prominent critical

\footnotetext{
${ }^{27}$ Recent work includes explorations of popular film and television works including Doctor Who and screen adaptations of Jane Eyre and Great Expectations; discussions of other cultural forms including the work of performer Emile Autumn; and Kathryn Bird's article 'The Animal, the Law, and "Victorian Values" in Kim Newman's Anno Dracula', Neo-Victorian Studies 7.1 (2014), 1-24.

28 These include Heilmann and Llewellyn's Neo-Victorianism (2010) and Helen Davies's Gender and Ventriloquism in Victorian and Neo-Victorian Fiction: Passionate Puppets (Basingstoke: Palgrave Macmillan, 2012).

${ }^{29}$ This is evident in the references to neo-Victorianism in Sabine Vanacker and Catherine Wynne's edited collection, Sherlock Holmes and Conan Doyle: Multi-Media Afterlives (Basingstoke: Palgrave Macmillan, 2012).
} 
definitions of neo-Victorianism, and in the genre's origins in postmodernism and the study of historiographic metafiction. This relationship is in itself problematic, given that postmodernism is not a monolithic term - a fact which should serve as a warning to neoVictorian scholars about their own critical definitions. The works of Byatt and her contemporaries participate in a 'knowing', self-conscious engagement with the Victorian age, and this, until relatively recently, has frequently been deemed a defining characteristic of neo-Victorian fiction within critical discourses (as well as one that implicitly excludes popular fiction from the genre). Heilmann and Llewellyn, in their widely cited work on the subject, sum up their use of the term 'neo-Victorianism' as follows:

[W]hat we explicitly seek to invoke in our use of the concept ['neoVictorianism'] is a series of metatextual and metahistorical conjunctions as they interact within the fields of exchange and adaptation between the Victorian and the contemporary. What we argue throughout this book is that the "neoVictorian" is more than historical fiction set in the nineteenth century. To be part of the neo-Victorianism we discuss in this book, texts ... must in some respect be self-consciously engaged with the act of (re)interpretation, (re)discovery and (re)vision concerning the Victorians[.] $]^{30}$

Indeed, Heilmann and Llewellyn not only privilege 'highbrow' literature - those texts which 'self-consciously engage' with Victorian literature and culture - but actively seek to exclude texts which do not meet this criteria:

\footnotetext{
${ }^{30}$ Heilmann and Llewellyn, Neo-Victorianism, p. 4 (my emphasis).
} 
All fictions post-1901 that happen to have a Victorian setting or re-write a Victorian text or a Victorian character do not have to be neo-Victorian; indeed, we would argue that many of them cannot be identified so precisely because they fall quite clearly into the category of historical fiction set in the nineteenth century rather than being texts about the metahistoric and metacultural ramifications of such historical engagement. ${ }^{31}$

A particular distinction is drawn, then, between neo-Victorian and historical fiction, and this is implicitly extended to the field of scholarship: it is an assertion of neo-Victorianism's critical credentials, emphasising its links with postmodernist criticism, rather than discourses of popular culture (Heilmann and Llewellyn refer to neo-Victorianism as 'one of [postmodernism's] prominent aspects'). ${ }^{32}$ In spite of this restrictive definition of neoVictorianism, Heilmann and Llewellyn's work is nevertheless important in terms of its attempt to expand the neo-Victorian canon. They observe:

[T]here is continuing evidence of the rather selective and self-perpetuating notion of a neo-Victorian canon. This is a danger inherent in the nature of adaptation and appropriation, but here it is not just that the same Victorian texts appear to be reworked, rewritten, and revisioned by contemporary writers, but also that critical work generates a sense of the neo-Victorian as identifiable within a small set of writers and texts. ${ }^{33}$

\footnotetext{
${ }^{31}$ Ibid., (my emphasis).

32 lbid., p. 245.

33 Ibid., p. 10.
} 
Through their focus on the first decade of the twenty-first century, and their discussion of a large number of texts ${ }^{34}$ (including Byatt and Waters), Heilmann and Llewellyn succeed in shifting the canonical boundaries of neo-Victorianism. However, this expansion is carefully mediated, and only takes place within certain defined parameters, drawing on the notion of 'self-conscious engagement' in neo-Victorian writing. Heilmann and Llewellyn's analysis is important not least because of their significant influence on subsequent critical definitions. ${ }^{35}$ Similarly, Kohlke and Gutleben, in their introduction to Neo-Victorian Gothic, emphasise the importance of texts 'self-consciously engaging with the nineteenth century'. ${ }^{36}$ Such descriptions echo critical definitions of metafiction as 'fictional writing which self-consciously and systematically draws attention to its status as an artefact in order to pose questions about the relationship between fiction and reality', ${ }^{37}$ although more recently Kohlke has suggested Heilmann and Llewellyn's definition 'proves inadequate for conceptualising the full range and diversity of neo-Victorian writing' ${ }^{38}$ Helen Davies, in Gender and Ventriloquism in Victorian and Neo-Victorian Fiction, also privileges writing which engages critically with the Victorian period, suggesting the term 'implies a genre of writing that is doing something with the Victorian era; critically engaging with nineteenthcentury fiction, culture, and society, as opposed to just repeating or nostalgically harking back to a past era'. ${ }^{39}$ Davies echoes this definition in her more recent work, Neo-Victorian Freakery (2015), asserting that 'one of the crucial features of neo-Victorianism is its commitment to critical engagements with the aesthetic form and ideological messages of

\footnotetext{
${ }^{34}$ In excess of twenty neo-Victorian texts are discussed at length, a number of them for the first time in the neo-Victorian context.

${ }^{35}$ Most subsequent monographs in the field cite Heilmann and Llewellyn's seminal study. Google Scholar shows it has been cited 166 times to date.

${ }^{36}$ Marie-Luise Kohlke and Christian Gutleben, eds, Neo-Victorian Gothic: Horror, Violence and Degeneration in the Re-Imagined Nineteenth Century (Amsterdam: Rodopi, 2012), pp. 1-48 (p. 10).

${ }^{37}$ Patricia Waugh, Metafiction (Abingdon: Routledge, 1984), p. 2.

${ }^{38}$ Kohlke, 'Mining the Neo-Victorian Vein', p. 25.

${ }^{39}$ Helen Davies, Gender and Ventriloquism in Victorian and Neo-Victorian Fiction, p. 2 (emphasis in original).
} 
nineteenth-century literature, ${ }^{40}$ although she also seeks to expand the traditional neoVictorian canon via discussion of the cultural influence of figures including Saartjie Baartman and P T Barnum. Similar language is employed elsewhere to describe the neo-Victorian project, with critics repeatedly returning to the idea of the text's 'self-conscious engagement' with Victorian literature and culture. Kym Brindle refers to 'works that selfconsciously engage the nineteenth century'; ${ }^{41}$ Robin Gilmour, in an essay which anticipates Heilmann and Llewellyn's definition, discusses 'the use which novelists have made of the Victorian period and its products in their fiction', and notes, 'By "use" I mean something more self-conscious than the straightforward historical novel with a period setting $;{ }^{42}$ while John Glendening highlights the 'metafictional self-awareness of much neo-Victorian fiction'. ${ }^{43}$

The prevalence of this notion of 'self-conscious engagement' with Victorian literature and culture in neo-Victorian scholarship raises some interesting questions: do other historical fictions with a Victorian setting - those which are not 'neo-Victorian' according to these critical definitions - fail to engage, or engage unself-consciously with the period on some level? How do we quantify the extent of the superficiality or otherwise of a text's engagement with the period? Is evidence of authorial scholarship in the field of Victorian studies required in order for the label 'neo-Victorian' to be applied (Waters, for

\footnotetext{
${ }^{40}$ Helen Davies, Neo-Victorian Freakery: The Cultural Afterlife of the Victorian Freak Show (Basingstoke: Palgrave Macmillan, 2015), p. 4.

${ }^{41}$ Kym Brindle, Epistolary Encounters in Neo-Victorian Fiction: Diaries and Letters (Basingstoke: Palgrave Macmillan, 2014), p. 4.

42 Robin Gilmour, 'Using the Victorians: The Victorian Age in Contemporary Fiction' in Rereading Victorian Fiction ed. by Alice Jenkins and Juliet John (Basingstoke: Palgrave, 2000), 189-200 (p. 189).

43 John Glendening, Science and Religion in Neo-Victorian Novels: Eye of the Ichthyosaur (Abingdon: Routledge, 2013), p. 9.
} 
instance, has a PhD in Victorian literature) $?^{44}$ Heilmann and Llewellyn seek to qualify the distinction they draw in this respect, noting, 'the divide between parody and innovation, pastiche and reinterpretation is an important demarcation that separates genres on the border between neo-Victorian texts and historical fiction set in the nineteenth century', ${ }^{45}$ but these borders are at times so indistinct as to be rendered illusive, if not invisible. Perhaps a more significant questions is why the manner in or level at which texts engage with Victorian literature and culture matters, according to these various critical definitions? Neo-Victorian scholarship is, by its own admission, concerned with exploring the relationship between past and present and representations of this relationship. Texts which engage at any level with the Victorian period necessarily reflect this relationship, and indeed may offer valuable insights about wider contemporary attitudes towards the past (in terms of nostalgic, false or misleading representations, for instance), therefore to dismiss them as irrelevant to the neo-Victorian project is potentially to overlook an important facet of the present's relationship to the Victorian past. In recent years, there has been a subtle acknowledgement of this via neo-Victorian scholarship's shifting definitions of the genre, and a move away from the defining emphasis being placed on self-conscious engagement.

\section{Expanding Critical Definitions}

Since the publication of Heilmann and Llewellyn's influential work, there is evidence of a move towards more expansive definitions of neo-Victorianism, which increasing include a wider range of genres and media, highlighting the ongoing process of canonical expansion. In an article published in 2013, Heilmann and Llewellyn reflect on critical shifts in neo-

\footnotetext{
${ }^{44}$ Significantly, a number of neo-Victorian novels include dual narratives focusing on the Victorian past and the text's present, including in the latter the figure of the Victorian scholar. These include Byatt's Possession and A. N. Wilson's A Jealous Ghost.

${ }^{45}$ Heilmann and Llewellyn, Neo-Victorianism, p. 6.
} 
Victorian scholarship, interrogating their own earlier critical position. They note that since the publication of their earlier work,

we have become increasingly alert to the international and global spheres in which the term "neo-Victorianism" is now deployed, or locations and moments in which, to us, there may be trace elements of potential engagement with the concepts behind neo-Victorianism as a larger global framework for discourses around nostalgia, heritage and cultural memory. ${ }^{46}$

In particular, the article focuses on two key issues: the global expansion of neo-Victorianism (a point I return to later), and the move of neo-Victorianism beyond the textual to the page, screen and stage - specifically its role in civic cultures and political/cultural moments (for example, the financial crash and ensuing protest movements). Neo-Victorianism, they contend,

has never been purely about textual or filmic adaptations of the nineteenth century: the genre of Steampunk, the culture of neo-Victorianism as a mode of dress, technological mash-up and subversion are all part of its resonance beyond literary-critical spaces but nevertheless informed by the same cultural frameworks as them. ${ }^{47}$

\footnotetext{
${ }^{46}$ Heilmann and Llewellyn, 'The Victorians Now: Global Reflections on Neo-Victorianism', Critical Quarterly 55.1 (April 2013), 24-42 (p. 24).

${ }^{47}$ Ibid., p. 34.
} 
This wider frame for the neo-Victorian project is reflected in other recent publications which explore beyond the traditional literary framework of the genre, including Iris KleineckeBates's Victorians on Screen (2014) and Claire Nally's forthcoming work, Steampunk: Gender, Subculture and the Neo-Victorian (2017). Both of these studies situate themselves firmly within neo-Victorian scholarship, a marked shift from earlier scholarship, in which Steampunk is frequently discussed in the context of popular fiction or cultural studies, and screen adaptations of Victorian literature and culture within the fields of film and adaptation studies.

Heilmann and Llewellyn's acknowledgment of a more expansive neo-Victorianism is to be welcomed, in particular the significant shift from 'self-conscious engagement' to 'trace elements of potential engagement', which opens up the field to a more diverse range of literary and cultural texts and moments. Nevertheless, popular culture remains on the peripheries of their vision of the field. Discussing the prevalence of the zombie trope in contemporary culture and its relevance to neo-Victorianism, they refer briefly to the “"mash-ups" of classic fiction', while noting somewhat dismissively that these works 'no doubt have "neo" relevance to someone'. ${ }^{48}$ However, their assertion that 'those who know the Victorian recognise its influence, those who unconsciously invoke its influence know not what they $\mathrm{do}^{\prime 49}$ has potentially significant ramifications for critical approaches to contemporary popular culture's engagement with the Victorian period.

Other critics have also proposed a more expansive interpretation of neoVictorianism - one which moves beyond the boundaries of self-conscious textual engagement and historiographical metafiction. Louisa Hadley defines the genre as 'contemporary fiction that engages with the Victorian era, at either the level of plot,

\footnotetext{
${ }^{48}$ Ibid., p. 33.

49 lbid., p. 35.
} 
structure, or both'. ${ }^{50}$ While acknowledging neo-Victorianism's links to postmodernism, Hadley also subscribes to the idea that 'the present return to the Victorians' represents 'a backlash against the cultural fragmentation which accompanies postmodernism': ${ }^{51}$ a more accurate reading of the relationship between neo-Victorianism and postmodernism, I contend, than those which essentially posit the former as a subgenre of the latter. In NeoVictorian Literature and Culture, Boehm-Schnitker and Gruss refer to the 'Neo-Victorian project', defined as 'an ongoing cultural and academic venture to analyse the manifold overlaps and intersections, the continuities and the breaches, between "us" and "them", and propose that 'neo-Victorianism has moved beyond postmodern concerns such as intertextuality, self-reflexivity or metafiction' ${ }^{52}$ In the same volume, Kohlke reflects on the possible expansion of the neo-Victorian canon to include both popular fiction, and global literatures, and (slightly belatedly) observes the danger that neo-Victorian critics 'reinscribe the highbrow/lowbrow divide, inviting accusations of a resurgent elitism of taste'. Yet she simultaneously suggests that 'contemporary romantic fiction appears somehow unappealing as an avenue of critical exploration' and suggests that 'few critics would want to extend the term "neo-Victorian" to include all romance novels set in the nineteenth century'. $^{53}$ Nonetheless, Kohlke's essay is an important acknowledgement of the state of the neo-Victorian canon and its critical discourses. Elizabeth Ho's Neo-Victorianism and the Memory of Empire (2012) also reaches beyond the traditional boundaries established by many neo-Victorian critics, exploring a diverse range of texts and genres, including graphic novels, the films of Jackie Chan, and steampunk, alongside well-established neo-Victorian

\footnotetext{
${ }^{50}$ Louisa Hadley, Neo-Victorian Fiction and Historical Narrative (Basingstoke: Palgrave Macmillan, 2010), p. 4.

51 lbid., p. 13.

52 Boehm-Schnitker and Gruss, pp. 1-2.

${ }^{53}$ Kohlke, 'Mining the Neo-Victorian Vein', pp. 29-30.
} 
authors such as Peter Carey. Ho notes neo-Victorianism's move beyond post-modernism towards a more encompassing field:

Representing a huge literary, cultural and academic industry, neo-Victorianism is now a term that links together the literary postmodernism of John Fowles' The French Lieutenant's Woman (1969) and the popularity of Michel Faber's scandalous serial epic The Crimson Petal and the White (2002), or the postauthentic aesthetics of the BBC "reality" series, Victorian Farm (Elliot, 2009) and the melodramatic Hollywood pastiche, Sweeney Todd (Burton, 2007) ${ }^{54}$

These assessments are reflective of a crucial shift in critical approaches, and a move beyond the established 'canonical' neo-Victorian highbrow literary texts. While 'literary' fiction continues to concern neo-Victorian critics, in recent years increasing attention has been paid to a wider range of cultural texts, including historical romance writing, burlesque performances, steampunk, musicals, detective fiction, theme parks, and popular television dramas. This highlights the rapid expansion of neo-Victorianism beyond its original canonical boundaries. Although neo-Victorian scholarship has been slow to acknowledge it, popular culture is now an integrated part of neo-Victorian studies, and its various forms constitute significant subgenres within neo-Victorianism, reflecting the ongoing process of canonical expansion. However, as the following section explores, unmediated expansion of the neoVictorian canon is not without its problems.

\section{Colonising Texts}

${ }^{54}$ Elizabeth Ho, Neo-Victorianism and the Memory of Empire (London: Bloomsbury, 2012) p. 4. 
The growth of the neo-Victorian canon to include an increasingly diverse array of works pertains not only to 'types' of fiction and other media (specifically popular cultural forms) but also to historical and geographical expansion, as works set outside of the boundaries of Victoria's reign and empire are increasingly cited as 'neo-Victorian'. While the expansion of neo-Victorianism beyond the historical and geographical boundaries of the Victorian age is representative of the blurred nature of generic boundaries more generally, nonetheless it remains problematic, indicative of the genre's paradoxical tendency to both include (beyond its obvious boundaries) and exclude (those texts which do not engage intellectually with the Victorian age). To limit neo-Victorianism to a focus solely on those texts set in Victorian Britain (and possibly its colonies) would be unnecessarily and distortedly restrictive: setting is not the only means through which a text can engage with the Victorian past. Diane Setterfield's The Thirteenth Tale (2001), for instance, is set in the twentieth century, but its intertexts, points of reference, and narrative structure are evidently Victorian. Similarly, Lloyd Jones's Mister Pip (2006), set in Papa New Guinea in the 1990s, might also legitimately lay claim to neo-Victorian status, through its engagement with Dickens's Great Expectations (1859). The latter, along with Jean Rhys's Wide Sargasso Sea, represents a key example of a neo-Victorian, post-colonial text: both Jones and Rhys engage directly with canonical Victorian novels, which serve as the ur-text for their own fictions. Elsewhere, however, (despite the genre's persistent engagement with the postcolonial) this blurring of boundaries is rendered problematic: less an act of reclamation than one of colonisation.

Novels set in the nineteenth century, but outside of the Victorian period and/or outside of Britain's borders are frequently deemed 'neo-Victorian' by certain expansive critical definitions. The 'Aims and Scope' of the journal Neo-Victorian Studies notes, '“[N]eo- 
Victorian" ... is employed in the widest possible sense, so as not to be restricted to geographical British contexts or those of the British Empire and its one-time colonies' ${ }^{55}$ In their edited series for Rodopi, Kohlke (editor of Neo-Victorian Studies) and Gutleben posit similarly broad definitions of the genre, as 'literature re-imagining and engaging the nineteenth century in global terms, not necessarily confined to only British or Britain's colonial contexts', and 'an umbrella term for all fiction self-consciously engaging with the nineteenth century regardless of evoked national and geographical contexts' ${ }^{56}$ Elsewhere, Kohlke expands her earlier definition of neo-Victorian to 'a generic and integrative umbrella term to encompass virtually all historical fiction related to the nineteenth century, irrespective of authors' or characters' nationalities, the plots' geographical settings, the language of composition or, indeed, the extent of narratives' self-consciousness, postmodernism, adaptivity or otherwise'.${ }^{57}$ Other critical definitions also imply an expansion beyond the chronological and/or geographical boundaries of the Victorian era, through the tendency to use the terms 'Victorian' and 'nineteenth century' interchangeably. ${ }^{58}$ Works set within and without Victorian Britain's colonies and demarcating dates are frequently discussed as neo-Victorian texts, but this represents a problematic act of literary colonisation with potential ethical implications. ${ }^{59}$

\footnotetext{
${ }^{55}$ Anon., http://www.neovictorianstudies.com/ [accessed 30 September 2016].

${ }^{56}$ Kohlke and Gutleben, eds, 'Introduction: Bearing After-Witness to the Nineteenth Century' in Neo-Victorian Tropes of Trauma: The Politics of Bearing After-Witness to Nineteenth-Century Suffering (Amsterdam: Rodopi, 2010), 1-34, (pp. 3, 10).

${ }^{57}$ Kohlke, 'Mining the Neo-Victorian Vein', p. 27.

${ }^{58}$ See, for example, Brindle, Epistolary Encounters, p. 4; Heilmann and Llewellyn, Neo-Victorianism, p. 7. The literal boundaries to the Victorian age - the ascension and death of Queen Victoria - are essentially arbitrary, and do not mark any specific social or cultural shift, yet the term remains useful for denoting the period and its contexts.

${ }^{59}$ Margaret Atwood's Alias Grace (1996), set in Canada, and Diane Setterfield's The Thirteenth Tale and Waters's The Little Stranger, in both of which narrative events take place after 1901, represent examples of texts often discussed within neo-Victorian criticism whose relationship to the Victorian is rendered problematic in this way. While not as prevalent, this trend is also evident in Victorian studies: a recent issue of Victorian Literature and Culture, for example, focuses on 'The Nineteenth-Century Pacific Rim'.
} 
Simon Joyce is one of a few critics to address this issue, questioning to what extent ... a label like "Victorian" [is] applicable to the present or past subjects of colonial rule?', and whether we can 'recognize different aspects of a residual Victorianism in (post)colonial states and subjectivities?'. ${ }^{60}$ Llewellyn's response to this in his review of Joyce's work is to propose that the 'imperial way of thinking' to which Joyce refers ${ }^{61}$ 'is in fact neo-imperialist in its intentions'. ${ }^{62}$ In Victoriana, Cora Kaplan is alert to some of the problems inherent in neo-Victorian postcolonial texts, noting the contemporary authorial tendency to 'privilege the story of European settlers over that of the non-white or indigenous population of the colonies'. ${ }^{63}$ Consequently, she suggests, 'Victoriana of this kind retroactively counters some Victorian prejudices, but leaves others, if only by default, in place'. ${ }^{64}$ Kaplan subsequently refers to contemporary novelists' tendency to 'cheerfully plunder' nineteenth-century writing, ${ }^{65}$ in a phrase which resonates with the critical tendency to claim the work of nonBritish writers as 'neo-Victorian'. Kaplan, in her concluding remarks, suggests Victoriana (her alternative term for neo-Victorian) 'has no choice about its participation in a much wider, transnational as well as national debate, reaching beyond the boundaries of Britain's former empire', ${ }^{66}$ but this statement does not address the implications of the critical neo-Victorian project in terms of its tendency to 'colonise' other (particularly non-British / nonAnglophone) literatures and cultures, ${ }^{67}$ though there is an earlier acknowledgement - if not an exploration - of this in Kaplan's stated intention to offer an 'analysis of Victoriana in

\footnotetext{
${ }^{60}$ Simon Joyce, The Victorians in the Rearview Mirror (Athens: Ohio University Press, 2007), pp. 166-7.

${ }^{61}$ Ibid., p. 169.

62 Mark Llewellyn, 'Shot Through with Ambiguities', Neo-Victorian Studies, 1.1 (Autumn 2008), 191-5 (p. 191).

${ }^{63}$ Cora Kaplan, Victoriana: Histories, Fiction, Criticism (New York: Columbia University Press, 2007), p. 155.

${ }^{64}$ Ibid., p. 155.

${ }^{65}$ Ibid., p. 156.

${ }^{66}$ Ibid., p. 162.

${ }^{67}$ Examples of these texts and cultural forms discussed within neo-Victorian scholarship include Japanese manga (Anna Maria Jones, "Palimpsestuous” Attachments: Framing a Manga Theory of the Global NeoVictorian', Neo-Victorian Studies, 8:1 [2015], pp. 17-47), and the works of Indian writer Amitav Ghosh and Egyptian author Ahdaf Soueif (both discussed in Heilmann and Llewellyn, Neo-Victorianism).
} 
some of the many genres it has colonised or invented from the 1960 s forward' ${ }^{68}$ Heilmann and Llewellyn include a chapter on 'Race and Empire: Postcolonial Neo-Victorians' in NeoVictorianism, exploring works by British, Indian, Egyptian, and Canadian authors. The discussion 'seeks to problematize the use of Victorian Orientalism and the postcolonial conceptualization of subalternity through the examination of a range of geographic and temporal locations', 69 but questions of whether 'neo-Victorian' stands as an appropriate label for these texts, its relevance for texts written and set outside of Britain's borders, and the potential implications of this, are not fully addressed, further contributing to the sense of critical neo-Victorianism as a colonising movement as well as highlighting its unstable generic boundaries. Kohlke recognises the problematic connotations of the term 'neoVictorian' as applied to 'postcolonial and subaltern literatures, or historical fictions of other nations that never were or, by the start of Queen Victoria's reign, were no longer British colonies', acknowledging that the label 'resurrects the. . spectres of imperialist exploitation and appropriation', but she suggests that 'such terminological tensions catalyse rather than curtail crucial debates about cultural memory and forgetting ${ }^{70}-$ a claim which appears to situate 'neo-Victorian', as applied to non-British literatures, as a provocative term intended to incite debate, but the ethics of which are, I suggest, questionable.

Recent scholarship has focused more intensely on the subject of global neoVictorianism(s) and its implications. Heilmann and Llewellyn address the issue of neoVictorianism 'going global' in their 2013 article:

\footnotetext{
${ }^{68}$ Kaplan, p. 4.

${ }^{69}$ Heilmann and Llewellyn, Neo-Victorianism, p. 28.

${ }^{70}$ Kohlke, 'Mining the Neo-Victorian Vein', p. 26.
} 
$[T]$ he focus remains largely on Anglophone engagements with Anglophone histories, stories and adaptations. Neo-Victorian criticism risks an implied imperialism in its response to such Anglocentricity. For the replacement - or displacement - of the term "neo-Victorianism" into international and global contexts is not without its own perils. ${ }^{, 71}$

They critique both the predominance of literary criticism and the Anglocentricity of neoVictorianism, and contend that 'the importance of extending beyond the relation of external empire and (post)colonial contexts into a wider panorama of the multiplex encounters with a Victorian tradition in a nineteenth-century perspective within a global environment is paramount'. ${ }^{72}$ Crucially, they point out that 'A global neo-Victorianism risks imposing collective memory over cultural specificity as part of the memorial imperialism', and ask, 'Can there be a global state of neo-Victorian studies, and should there be? ${ }^{73}$ Ultimately, though, they veer towards the conclusion that the future of the field lies on the global stage, without offering any comprehensive analysis or solutions in terms of the potential ethical problems this poses.

Ho, too, engages with the shifting terrain of neo-Victorianism, towards a global stage, in her analysis of the 'neo-Victorian-at-sea', although in discussing empire, the link to Victorian Britain remains evident:

The neo-Victorian-at-sea reframes British imperialism as a fluid and shifting political space freeing the genre from the referent of Britain. Without Britain as

\footnotetext{
${ }^{71}$ Heilmann and Llewellyn, 'The Victorians Now', p. 26.

72 Ibid., p. 28.

${ }^{73}$ Ibid., pp. 37, 39.
} 
an anchor, however, the neo-Victorian-at-sea presents us with an unbounded globality that offers a rejuvenation of the field but also threatens to unravel the genre itself. $^{74}$

For Ho, then, the British connection remains crucial in order to grant the genre some form of coherence. In 2015, Neo-Victorian Studies published a special issue on 'Neo-Victorianism and Globalisation'. The subtitle of the issue, 'Transnational Dissemination of NineteenthCentury Cultural Texts', hints at the potential problems of a global genre which casts itself as 'neo-Victorian', when 'neo-nineteenth-century' is a more accurate description of its status. In their introduction, the editors seek to define global neo-Victorianism, questioning 'the applicability of the term "neo-Victorian" outside the sphere of British imperial influence, but nevertheless arguing for 'the reach and relevance of neo-Victorianism beyond the borders of the British Empire and the English language'. ${ }^{75}$ Neo-Victorianism, they argue, 'can go global to reference new contexts and geographies of Victorian texts' and contexts' engagement with local, inter and transnational nineteenth-century pasts without necessarily being reductionist or immediately risking a homogenising, imperialist perspective' ${ }^{76}$

Yet the problem with global neo-Victorianism, as some of these critiques suggest, is precisely the 'Victorian'. The label has long had problematic associations: at various points invoking something unfashionable, regressive, conservative, jingoistic, repressed, traumatic, or shameful - connotations often acknowledged by neo-Victorian criticism. However, the seemingly casual expansion of the neo-Victorian canon to include works set or produced

\footnotetext{
${ }^{74}$ Ho, p. 6.

75 Monika Pietrzak-Franger and Antonija Primorac, 'What is Global Neo-Victorianism?', Neo-Victorian Studies 8.1 (2015), 1-16 (p. 1).

${ }^{76}$ Ibid., p. 7 (emphasis in original).
} 
both inside and outside the geographical and chronological borders of Victorian Britain often does not take sufficient account of these multiple connotations of the term. Indeed, such casual definitions of the genre require greater critical interrogation: the term is used expansively and inclusively because it is convenient to do so, making available a wider array of texts for critical investigation, and avoiding the need for reference to an extensive variety of alternative genres, such as 'neo-Romantic', 'neo-Georgian', 'neo-Regency', and 'neonineteenth century' - the latter a more accurate, if less linguistically appealing description. Ironically, then, the textual interrogation that is frequently demanded by neo-Victorian critics from fictional works appears absent from some of their own terminology. Prior to the establishment of 'neo-Victorian' as the preferred term to describe this genre of writing and the scholarship around it, several other terms were proposed, including 'Retro-Victorian', 'Post-Victorian', and 'Victoriana'. Significantly, all these terms emphasise the Victorian element of the works with which they are concerned. In his review of Joyce, Llewellyn refers to 'the fractured interpretations of the Victorian circulating through British culture since the turn of the nineteenth century, ${ }^{77}$ but there is less acknowledgement and interrogation of these diverse interpretations in critical uses of the term 'neo-Victorian'. While scholarship deconstructs Victorian literature and culture, the myths that surround it, and our own relationship with it, through its exploration of contemporary fiction, there appears to be a greater reluctance to explore the meanings of the term 'Victorian' and its use within neoVictorianism. There is a paradox operating here: at the heart of neo-Victorian writing (fiction and criticism) is an attempt to explore the complexities of the relationship between the Victorian past and the contemporary present, but the potential complexity of the term 'neoVictorian' itself is frequently overlooked, through the critical tendency to use it expansively

\footnotetext{
${ }^{77}$ Llewellyn, p. 191.
} 
to refer to works engaging in some way with the nineteenth century more generally. The notion of multiple Victorian pasts is fully acknowledged in neo-Victorian writing and scholarship; what is not sufficiently interrogated is the multitude of neo-Victorian and associated discourses - neo-Victorianism as something more than a single, coherent, unified discourse. While a number of critical works focusing on subgenres or specific themes and motifs of neo-Victorian fiction have emerged, generalisations about the wider genre are commonplace, with critics making large claims for the genre as a whole in a manner which seems unrealistic (consider the implausibility of generalisations about the Victorian novel: it does not operate as a single entity, or even a unified genre). 'Neo-Victorianism' is frequently referred to in the singular, implying a coherent, identifiable entity. Llewellyn suggests 'the neo-Victorian constitutes a particularly pressing theme in the post-millennial moment', ${ }^{78}$ while Stetz, writing about 'the neo-Victorian novel' suggests 'its features have become so familiar and readily distinguishable' that it now lends itself to parody. ${ }^{79}$ Such generalisations have reinforced notions of canonicity within the genre by reiterating assertions that neoVictorian texts operate in specific ways - assertions which then serve to exclude those texts which do not conform to such criteria. Ultimately, then, such generalisations potentially reinforce the exclusion, or at least the marginalisation, of certain works as much as they appear to express inclusivity.

\section{Conclusion}

The boundaries and dichotomies between the various categorisations proposed by critics - literary/popular, highbrow/middlebrow/lowbrow, neo-Victorian/historical fiction are inextricably blurred. Consequently, particularly in light of continuing canonical

\footnotetext{
${ }^{78}$ Ibid., p. 191.

${ }^{79}$ Stetz, p. 339.
} 
expansion and shifting critical perceptions, the terminology and definitions associated with neo-Victorianism stand in need of review. Given the recent (and continuing) movements and developments in the field, not least the expansion of the canon to include the popular and the global, the question arises of whether 'neo-Victorian' remains the most appropriate label for this genre of writing, or indeed whether such diverse texts can be accurately said to constitute a coherent genre. Critical debates around the term 'neo-Victorian' have resulted in the concept being imbued with connotations of postmodernism and historiographic metafiction, whereas it is evident that many of the works discussed under this label do not necessarily embody those characteristics. The list of possible terms put forward to describe this complex and diverse genre is already lengthy (neo-, post-, retro-, and faux- Victorian, Victoriana, Victoriography), and 'neo-Victorian' now firmly established as the favoured term. In light of the prevailing connotations of the term, this may not be the most appropriate label for works engaged with the nineteenth century and may more accurately allude to a subgenre (with the implied associations to postmodernism) within a larger field of scholarly investigation, which includes a broader range of texts and genres, as well as wider cultural issues.

However, the terminology associated with this genre of fiction and scholarship is unlikely to change - not least because online technologies and search engine optimisation provide a clear advantage to scholars using an already established phrase in terms of the visibility of their work. In an article which appeared in the inaugural issue of Neo-Victorian Studies in 2008, Andrea Kirchknopf revisits the terminology relating to the genre, and concludes that the preferable term for this type of writing is 'post-Victorian', ${ }^{80}$ somewhat ironically given that the founding of the journal effectively established 'neo-Victorian' as the

\footnotetext{
${ }^{80}$ Kirchknkopf, p. 66.
} 
favoured critical term. Nevertheless, the neo-Victorian canon is growing, metamorphosing into a more expansive and inclusive category. Currently, the two clearest trends are the increasing acknowledgement of the significance of popular culture, and the inclusion of global texts. As a consequence of these developments, the meanings of the term 'neoVictorian' are gradually shifting - away from its post-modern roots and towards a broader definition. While the expansion of the neo-Victorian canon is to be broadly welcomed, particularly in terms of the inclusion of popular literature and culture which serves to call into question notions of cultural hierarchies and elitism, neo-Victorian scholarship must not be blind to the potential ethical implications of the inclusion of certain narratives within the genre: neo-Victorian canonical expansion must seek to avoid acts of literary colonisation.

The terminology may not shift but our critical understanding of its ethical implications must be clearly articulated if it is to evade accusations of (textual/cultural) colonialism. The expansion of the neo-Victorian canon beyond traditional 'literary' texts, to include a more diverse range of popular fiction, film, television, and other cultural forms parallels the earlier expansion of the Victorian canon beyond F. R. Leavis's 'Great Tradition'. However, the broadening of the neo-Victorian canon beyond geographical boundaries towards a genre which admits global literatures engaging with the nineteenth-century is more problematic, and should be treated with caution, not merely because the inclusion of these works threatens to render the term 'neo-Victorian' essentially meaningless, but, more importantly, because their inclusion signifies a continued privileging of the (British) 'Victorian' over other histories and cultures. Global neo-Victorian narratives should, by definition, retain the Victorian association - whether via the translation of Victorian cultural texts, lives, and moments, or through links to empire and the experiences of the Victorians themselves on the global stage. Those works which deal exclusively with the history of 
countries and cultures beyond the Victorian must remain outside the neo-Victorian genre not in order to preserve the Anglocentricity of neo-Victorianism, but precisely the opposite: to acknowledge the existence of global and cultural traditions beyond the Victorian, and to avoid neo-imperialistic claims of belonging. ${ }^{81}$ Neo-Victorianism, as a critical discourse and cultural genre, is here to stay, but its meanings continue to shift: scholars must ensure that these shifts occur within an appropriate ethical framework.

\footnotetext{
${ }^{81}$ This is not to say that those works which engage with multiple traditions and cultures which include the Victorian should not be discussed under the neo-Victorian banner, but their engagement with different cultures - and their potentially problematic status as neo-Victorian works - must also be acknowledged.
} 